Life Sciences Contribution

Royal Ontario Museum

95

\title{
Mammals from the St. Mary River \\ Formation (Cretaceous) of Southwestern Alberta
}

Robert E. Sloan, Loris S. Russell

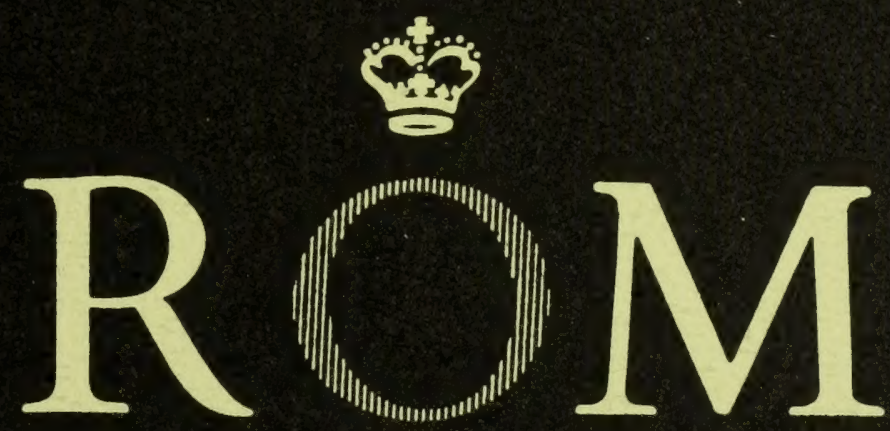


Digitized by the Internet Archive in 2011 with funding from University of Toronto 
LIFE SCIENCES CONTRIBUTIONS

ROYAL ONTARIO MUSEUM

NUMBER 95

Robert e. SLOAN, Mammals from the

LORIS S. RUSSELl St. Mary River

Formation (Cretaceous) of

Southwestern Alberta 


\section{ROYAL ONTARIO MUSEUM PUBLICATIONS IN LIFE SCIENCES}

The Royal Ontario Museum publishes three series in the Life Sciences:

LIFE SCIENCES CONTRIBUTIONS, a numbered series of original scientific publications, including monographic works.

LIFE SCIENCES OCCASIONAL PAPERS, a numbered series of original scientific publications, primarily short and usually of taxonomic significance.

LIFE SCIENCES MISCELLANEOUS PUBLICATIONS, an unnumbered series of publications of varied subject matter and format.

All manuscripts considered for publication are subject to the scrutiny and editorial policies of the Life Sciences Editorial Board, and to review by persons outside the Museum staff who are authorities in the particular field involved.

LIFE SCIENCES EDITORIAL BOARD

Chairman, R. L. PETERSON

Editor, J. R. TAMSITT

Associate Editor, D. BARR

Associate Editor, E. J. CROSSMAN

ROBERT E. SLOAN is Professor in the Department of Geology and Geophysics, University of Minnesota, Minneapolis, Minnesota.

LORIS S. RUSSELL is Curator Emeritus in the Department of Vertebrate Palaeontology, Royal Ontario Museum, Toronto, Ontario.

PRICE: $\$ 2.00$

(C) The Royal Ontario Museum, 1974

100 Queen's Park, Toronto, Canada

PRINTED AT THE BRYANT PRESS LIMITED 


\title{
Mammals from the St. Mary River Formation (Cretaceous) of Southwestern Alberta
}

\begin{abstract}
A small collection of mammalian teeth, mostly fragmentary, is described from the St. Mary River Formation of southwestern Alberta. All but one are from near the base of the formation at Scabby Butte, northwest of Lethbridge. These represent three species of multituberculates, four species of marsupials, and a possible fissiped. A single multituberculate tooth of a fourth species, from near the top of the formation on Oldman River north of Lundbreck, is also described. Genera represented are those of the Lance and Oldman faunas.
\end{abstract}

\section{Introduction}

The St. Mary River Formation is a piedmont coastal plain deposit composed of stream channel and flood plain sediments of late Campanian and Maastrichtian age. It occurs within a radius of 60 miles north, east, and south of the Waterton-Glacier International Peace Park in Alberta and Montana. Mammals from this formation at two localities in southwestern Alberta add to the biostratigraphic range of certain fossil species.

The geologically younger of these two localities is near the top of the St. Mary River Formation in the Disturbed Belt, on the south bank of Oldman River, 15 miles north of Lundbreck, Alberta. The occurrence (St. Mary River Formation locality 11 of Tozer, 1956) is 39 feet (12 meters) below the contact with the overlying Willow Creek Formation. The location is in legal subdivision 11 , section 6 , township 10 , range 1 west of the 5 th meridian, Alberta, approximately $\mathrm{W}$ long $114^{\circ} 08^{\prime}$ and $\mathrm{N}$ lat $49^{\circ} 47^{\prime}$. In $1951 \mathrm{E}$. T. Tozer collected a single $\mathrm{M}_{2}$ of Cimolodon nitidus Marsh from a coquina bed of "Unio" stantoni White, Viviparus sp. and Lioplacodes sp. (Tozer, 1952). Subsequently only unidentified bone chips were collected here.

The second locality is Scabby Butte, three miles northeast of Nobleford and one mile south of Keho Lake, Alberta. The first mammals from here were discovered in 1957 by Wann Langston, Jr. (Russell, 1962), and additional specimens were collected intermittently by Langston, L. S. Russell, and R. L. Fowler. The locality is in legal subdivision 11, section 18, township 11 , range 22 west of the 4 th meridian, Alberta, approximately W long $113^{\circ}$ $00^{\prime}$ and $\mathrm{N}$ lat $40^{\circ} 55^{\prime}$. About 1000 feet (300 meters) to the east is the bone bed from which skulls of the peculiar ceratopsid Pachyrhinosaurus canadensis were obtained (Sternberg, 1950; Langston, 1967). Beds in which the mammalian teeth occur are a few feet higher in the section. The contact with the underlying Bearpaw Shale is probably just below the base of the exposure, 
as shells of brackish water mollusks occur in the rill channels of the outwash plain immediately in front of the cliff. The fossil beds at Scabby Butte are in the same stratigraphic level of the formation as that from which Barnum Brown collected the protoceratopsid Montanaceratops cerorhynchus (Brown and Schlaikjer, 1942; Sternberg, 1951, p. 227), just south of the International Boundary, in or near section 20, township 36 north, range 9 west, Glacier County, Montana, about $\mathrm{N}$ lat $48^{\circ} 52^{\prime}$, W long $112^{\circ} 50^{\prime}$. (The numbering of sections in a township is different in Canada and the United States: section 1 in the U.S. is at the northeast corner and 36 at the southeast, whereas in Canada, section 1 is at the southeast corner and section 36 at the northeast. The numbering patterns are thus symmetrical about the International boundary.)

The St. Mary River Formation is laterally equivalent to the Lower and Middle Members of the Edmonton Formation to the north and east, as defined by Allan and Sanderson (1945), or to the Edmonton Group of Irish (1970). To the south it is laterally equivalent to, and grades into, a portion of the Livingston Formation. The marine equivalents are the ammonite zones Baculites eliasi through Baculites clinolobatus of the Bearpaw and Pierre Shales (Gill and Cobban, 1966, pl. 4). The St. Mary River Formation is overlain by the Willow Creek Formation, which is in part latest Cretaceous (Maastrichtian) and partially Paleocene in age (Bell, 1949; Tozer, 1956). Outcrop of the St. Mary River Formation is restricted to the Alberta syncline from township 14 in Alberta (84 miles north of the International Boundary) to township 28 north in Montana (about 60 miles south of the International Boundary). The thickness of the formation on the eastern limb of the Alberta syncline is about 1,200 feet ( 370 meters) and on the western limb, adjacent to the thrust belt, about 2,500 feet (760 meters). In the Lethbridge area, the base of the St. Mary River Formation is late Campanian; the latest marine guide fossils in the upper portion of the Bearpaw Shale and the Blood Reserve Sandstone beneath the St. Mary River Formation are from the Baculites reesidei zone (Gill and Cobban, 1966). The base of the St. Mary River Formation is coeval with the base of the Edmonton Formation (Langston, 1967; Russell, 1970) and consequently is at the base of the Edmontonian Stage (Russell, 1964). Specimens from Scabby Butte thus provide the only described sample of mammals from the latest Campanian and the Edmontonian Stage. The Hunters Wash local fauna presently being described by Clemens from near the contact between the Kirtland and the Fruitland Formations of New Mexico is of similar or slightly younger age (Clemens, 1971). In the list and descriptions that follow, the multituberculates were identified and discussed by Sloan, and the therians were identified and discussed by Russell.

\author{
Subclass Allotheria \\ Order Multituberculata \\ Suborder Taeniolabidoidea \\ Family Cimolomyidae \\ Cimolomys gracilis Marsh, 1889 (sensu Clemens, 1963 rather \\ than sensu Simpson, 1929)
}


Meniscoessus conquistus Cope, 1882

Suborder Ptilodontoidea

Family Ectypodontidae

Mesodma cf. thompsoni Clemens, 1963

\section{Subclass Theria}

Order Marsupialia

Suborder Didelphoidea

Family Didelphidae

Pediomys cf. cooki Clemens, 1966

Pediomys cf. krejcii Clemens, 1966

Family Stagodontidae

Didelphodon? sp.

Eodelphis? sp.

Order Carnivora?

Suborder Fissipeda?

Family Miacidae?

Genus and species undetermined

In addition to the rare mammalian teeth, the Scabby Butte locality yielded numerous teeth of the ray Myledaphus sp., scales of Lepisosteus sp., vertebrae of Champsosaurus sp., crocodile teeth (probably Leidyosuchus sp.), teeth and bones of carnosaurs, hypsilophodontids [? Parksosaurus warreni (Parks) ], hadrosaurs, ceratopsians, nodosaurs, and numerous fragments of turtle shells. Poorly preserved shells of unionids and viviparids are common, forming three separate shell beds at intervals of 2-3 feet. As usual most of the bones and teeth are concentrated in the shell beds.

\section{Materials}

The specimens described in this paper are in the National Museum of Natural Sciences, National Museums of Canada (NMC) and the Royal Ontario Museum (ROM). References are made to specimens in the American Museum of Natural History (AMNH), the South Dakota School of Mines (SDSM), and the University of California Museum of Paleontology (UCMP). 


\title{
Descriptive Palaeontology
}

\author{
Subclass Allotheria \\ Order Multituberculata \\ Suborder Taeniolabidoidea Sloan and Van Valen, 1965 \\ Family Cimolomyidae Marsh, 1889
}

This family was proposed by Marsh at the time that he described the Lance mammals but was not employed in any useful way until resurrected by Sloan and Van Valen (1965) for Cimolomys and Meniscoessus. A revised diagnosis of the family was given by Sahni (1972, written in 1967). Some additional comments follow. The members of this family retain a few morphological features characteristic of mid-Cretaceous multituberculate species, while undergoing certain progressive evolutionary trends different from those of the Ptilodontoidea. There is a progressive development of efficient incisor shear, culminating in the development by wear of a restricted enamel band and self-sharpening lower incisor in some individuals of Meniscoessus. In contrast to the members of the related families Taeniolabididae and Eucosmodontidae, no member of the Cimolomyidae has a lower incisor with a circular lateral profile and continuous extrusion of the lower incisor to compensate for wear. The profiles and serration counts of $\mathrm{P}_{4}^{4}$ remain low, resembling many Bain Dzak (Djadochta) species, while cusp number and size of $\mathrm{M}_{1}^{1}$ continuously increase. Thus the diagnostic ratio, length $\mathrm{P}_{4} /$ length $\mathbf{M}_{1}$, becomes progressively reduced. In addition, the shape of the molar cusps becomes more complicated than in most multituberculates by the development of wings and buttresses, producing an increase in molar shear surfaces.

Cimolomys is based on Cimolomys gracilis Marsh (1889), a taxon described by Marsh from specimens collected at Lance Creek, Wyoming. Simpson (1929), as an expedient only, used this name for almost all late Cretaceous multituberculates not referable to Meniscoessus. Most later authors followed his usage until Clemens (1963), after the discovery of many jaws, revised the late Cretaceous multituberculates and redefined $C$. gracilis to limits comparable to other multituberculate species. Cimolomys also includes $C$. trochuus Lillegraven (1969) from the Scollard (Upper Edmonton) Formation of Alberta, a small species C. clarki Sahni (1972) from the mid-Campanian Judith River Formation of Montana, and two unnamed species from the early Campanian Milk River Formation of Alberta (Fox, 1971). Meniscoessus, with type species $M$. conquistus Cope (1882) from the Hell Creek Formation or northwestern South Dakota (Wilson, 1965; Van Valen, 1967), was referred to this family by Sloan and Van Valen (1965). The other species of Meniscoessus are M. robustus (Marsh, 1889) from the Lance Formation of Wyoming, M. borealis Simpson (1927) from the Hell Creek Formation of Montana, both of Maastrichtian age, M. major (Russell, 1936) from the mid-Campanian Oldman and Judith River Formations of Alberta and Montana, and M. ferox Fox (1971) from the early Campanian Milk River Formation of Alberta. 
Outside of North America, Buginbataar transaltaiensis Kielan-Jaworowska and Sochava (1969), from the last Campanian or Maastrichtian of the Bugin Cav region of Mongolia, was originally referred to the Cimolomyidae with considerable justification.

\section{Cimolomys gracilis Marsh, 1889}

Cimolomys gracilis Marsh, 1889, p. 84.

Cimolomys gracilis, Simpson, 1927, p. 107 (in part).

Cimolomys gracilis, Clemens, 1963, p. 76.

Cimolomys gracilis, Lillegraven, 1969, p. 30.

REFERRED SPECIMENS

NMC $17662,17663,17664$, three tooth fragments from at least two individuals, from Scabby Butte.

\section{KNOWN DISTRIBUTION}

Lance Formation, Wyoming; Hell Creek Formation, Montana and South Dakota; Scollard ("Upper Edmonton") Formation, Alberta; lower St. Mary River Formation, Alberta.

\section{DESCRIPTION}

NMC 17662 (Figs. $1 \mathrm{~A}-\mathrm{C}, 5 \mathrm{~A}-\mathrm{C}$ ) is the posterior half of a right $\mathrm{P}^{4}$ (preserved length, $1.8 \mathrm{~mm}$; estimated total length, $2.5 \mathrm{~mm}$ ). The tooth is clearly referable to this species, and its size is appropriate to occlude with $\mathrm{P}_{4}$ about $4.3 \mathrm{~mm}$ long. It is moderately worn and differs insignificantly from previously described specimens (Clemens, 1963).

NMC 17663 (Figs. 1D,E 5D,E) is the posterior half of a scarcely worn left $\mathrm{P}_{4}$ (preserved length, $2.4 \mathrm{~mm}$; estimated total length, $4.3 \mathrm{~mm}$ ). Striations descend only from the first three of the preserved five serrations both on the medial and lateral faces, as is characteristic of Cimolomys. In addition, the ultimate and penultimate serrations are hooked posteriorly, another unique feature of the genus.

NMC 17664 (Figs. 1F-H, 5F-H) is a very tiny fragment of a right $\mathrm{M}^{1}$, and consists of the penultimate and antepenultimate cusps of the external row. The antepenultimate cusp is hooked anteriorly, the penultimate less so as in previously figured specimens (Clemens, 1963, fig. 37). Characteristic buttresses and wings serve to increase the effectiveness of the anteriorposterior grinding shear. The intercusp spacing $(0.50 \mathrm{~mm})$ is at the lower size limit for the species at Lance Creek.

\section{REMARKS}

The three specimens are at the smallest extreme of the observed size range of specimens from the Lance Formation. With more complete and numerous specimens, separation at the specific level might prove useful, especially since these specimens are earlier than all the others known, and the presumed ancestor $C$. clarki is much smaller. Such separation is not warranted at present. 


\section{Meniscoessus conquistus Cope, 1882}

Meniscoessus conquistus Cope, 1882, p. 340.

Meniscoessus conquistus, Simpson, 1929, p. 102.

Meniscoessus conquistus, Van Valen, 1967, p. 1.

TYPE SPECIMEN

AMNH 3011 , slightly damaged right $\mathbf{M}^{2}$.

\section{REFERRED SPECIMENS}

Six uncatalogued SDSM teeth, a humerus, and a tibia, all collected by R. W. Wilson less than a mile from the type locality in Harding County, South Dakota. Three teeth from at least two individuals ( вом 7846, 7847, 7850) from Scabby Butte.

KNOWN DISTRIBUTION

Lower(?) Hell Creek Formation, Harding County, South Dakota; lower St. Mary River Formation, Scabby Butte, Alberta.

\section{DESCRIPTION}

ROM 7846 (Fig. 5I,J) is a tricuspid anterior upper premolar, $\mathrm{P}^{1}$ or $\mathrm{P}^{2}$ of Meniscoessus. Dimensions are: length, $2.1 \mathrm{~mm}$; width, $1.8 \mathrm{~mm}$.

ROM 7847 (Figs. 2, 5K) is a left $\mathrm{M}^{2}$ (length, $6.5 \mathrm{~mm}$; width, $4.7 \mathrm{~mm}$ ), with a cusp formula of $3 ?: 4: 4$, belonging to an extremely old individual. The tooth, the last to erupt, was so worn by attrition during life, that the relief of the surface is less than $0.5 \mathrm{~mm}, 70 \%$ of the enamel is worn away, and pulp cavities are exposed in six of the eight major cusps. The crescentic character of the cusps and the buttresses and crenulations in the enamel that occur on the flanks of the two main anterior-posterior groves are conspicuous. The anterior median cusp is a thin plate which is not always counted in determining cusp formula but in this tooth is clearly distinguishable.

\section{REMARKS}

Size, cusp shape and buttressing indicate that this tooth is indeed that of Meniscoessus. But the tooth is distinctly smaller than the observed size range of $M$. robustus from the Lance Formation of Wyoming (Clemens, 1963, p. 93) and that of the even larger $M$. borealis from the upper Hell Creek Formation of Montana (Simpson, 1927; Sloan, unpubl. data). The only tooth of comparable size is the type, an $\mathrm{M}^{2} 6.5 \mathrm{~mm}$ long and $5.2 \mathrm{~mm}$ wide, of $M$. conquistus from the basal Hell Creek Formation of Northwestern South Dakota. In addition, R. W. Wilson collected two $\mathrm{M}^{2}$ 's (both $7.3 \mathrm{~mm}$ long, one $6.1 \mathrm{~mm}$ wide) from less than a mile from the type locality of $\boldsymbol{M}$. conquistus (Wilson, 1965, pers. comm.; Van Valen, 1967).

It is thus now possible to make " $t$ " tests of the significance of difference of means of lengths of $\mathrm{M}^{2}$, to determine the validity of Marsh's species $M$. robustus with respect to Cope's earlier species $M$. conquistus, and to compare both to the Scabby Butte specimen. The probability of difference between the three South Dakota specimens of $M$. conquistus and the 24 specimens of the Lance sample of $M$. robustus (Clemens, 1963, p. 93) is .92 , which is 
significant; the comparison between the Scabby Butte specimen and the Lance specimens has a probability of difference of .90 , which is also significant; but the comparison between the Scabby Butte specimen and the South Dakota specimens has a probability of difference of .77 , which is clearly not significant. Thus $M$. conquistus and $M$. robustus are valid species and ROM 7847 is referable to $M$. conquistus.

ROM 7850 (Figs. 3A-C, 6A-C) is an additional specimen of $M$. conquistus and consists of the ultimate and penultimate cusps from the medial row of a right $\mathbf{M}_{2}$. The tooth is scarcely worn, probably erupted shortly before the animal's death. Wear facets extend only a third of the way down the outer flanks of the cusps and halfway down the medial face of the penultimate cusp. Cusps are crescentic and bear the medial buttressing characteristic of Meniscoessus. The preserved length is $3.9 \mathrm{~mm}$, estimated length is $6.8 \mathrm{~mm}$; preserved width is $1.8 \mathrm{~mm}$, estimated width is $3.3 \mathrm{~mm}$. These estimated dimensions are smaller than those of the smallest $M$. robustus and are appropriate for $M$. conquistus.

\section{Suborder Ptilodontoidea Sloan and Van Valen, 1965 Family Ectypodontidae Sloan and Van Valen, 1965 Mesodma cf. thompsoni Clemens, 1963}

\section{REFERRED SPECIMEN}

NMC 17665 (Figs. 4A-C, 6D-F), from Scabby Butte.

\section{DESCRIPTION}

This specimen is a left $\mathrm{P}^{3}$, the size of which is comparable to that of the common species $M$. thompsoni. The tooth has four cusps. Length is $1.5 \mathrm{~mm}$ and width is $0.85 \mathrm{~mm}$. The species is known from the Lance Formation of Wyoming, Hell Creek Formation of Montana, Scollard ("Upper Edmonton") Formation of Alberta, and the basal Nacimiento Formation of New Mexico. The presence of this wide ranging species at Scabby Butte is not unexpected.

\section{Family Cimolodontidae Marsh, 1889 Cimolodon nitidus Marsh, 1889}

Cimolodon nitidus Marsh, 1889, p. 84.

Cimolodon nitidus, Clemens, 1963, p. 56.

Cimolodon nitidus, Lillegraven, 1969, p. 27.

REFERRED SPECIMEN

NMC 17667 (Fig. 6G), a right $\mathrm{M}_{2}$ from locality 11, 15 miles north of Lundbreck, Alberta (Tozer, 1956).

\section{KNOWN DISTRIBUTION}

Lance Formation, Wyoming; Hell Creek Formation, Montana and South Dakota; Kirtland and Fruitland Formations, New Mexico; Scollard ("Upper Edmonton") Formation, Alberta; uppermost St. Mary River Formation, Alberta. 


\section{DESCRIPTION}

This tooth, from the top of the St. Mary River Formation on the western side of the Alberta syncline in the foothills, is not distinguishable from specimens from the Lance or Hell Creek Formations. Moderately worn, it is $2.8 \mathrm{~mm}$ long, and $2.2 \mathrm{~mm}$ wide. The cusp formula is $4: 2$, which is the modal formula of the sample from the Lance Formation. The sculpture or the medial faces of the cusps of NMC 17667 is comparable to the Lance specimens, as is the size. The tooth is smaller than the specimens from the Scollard Formation of Alberta.

\section{Subclass Theria \\ Order Marsupialia \\ Suborder Didelphoidea \\ Family Didelphidae \\ Pediomys cf. cooki Clemens, 1966}

\section{REFERRED SPECIMEN}

NMC 21307 (Fig. 6H), buccal portion of right upper molar, probably $\mathbf{M}^{2}$, from Scabby Butte.

\section{DESCRIPTION}

The specimen includes the stylar margin and the paracone and metacone, but the more lingual part of the crown has been broken away. The buccal margin is slightly indented at midlength. Stylar cusp A is prominent; stylar cusp B is low, with the main apex opposite the apex of the paracone, but with a second, vestigial apex posterior; stylar cusp $\mathrm{C}$, opposite the paracone-metacone gap, is vestigial; stylar cusp D is as prominent as A but more conoid; stylar cusp E (metastyle) is the enlarged buccal termination of the posterobuccal crest from the metacone; area between this posterobuccal crest and stylar cusp D is basin-shaped. The paracone is high and sharply conoid, slightly flattened on the side facing the metacone, and not interrupting the buccal cingulum; metacone conoid, slightly truncated by wear at the tip, but originally about as high as the paracone, and slightly flattened on paracone and buccal sides; except for posterobuccal crest mentioned above there are only obscure vestiges of an ectoloph. In outline the crown was evidently an oblique triangle, similar in shape to the $\mathrm{M}^{2}$ of Didelphis virginiana. Anteroposterior dimension, measured along buccal margin is $2.0 \mathrm{~mm}$.

\section{REMARKS}

This specimen falls within the diagnosis of the genus Pediomys (Clemens, 1966, p. 34), with subequal paracone and metacone, narrow stylar shelf at paracone, and reduced stylar cusps B and C. The size of the tooth is most comparable to that of $P$. elegans and $P$. cooki of the Lance Formation, but is distinguished from the former by the vestigial nature of stylar cusp B. Stylar cusp $\mathrm{D}$ is larger than that of $P$. cooki, but otherwise the fragment is more similar to the upper molars of that species than to those of $P$. elegans. 


\section{Pediomys cf. krejcii Clemens, 1966}

REFERRED SPECIMEN

NMC 9820 (Fig. 6I-K), right M $_{1}$, from Scabby Butte.

\section{DESCRIPTION}

NMC 9820 is a very small tooth, measuring $1.7 \mathrm{~mm}$ anteroposteriorly (parallel to the lingual margin) and $0.95 \mathrm{~mm}$ (at right angle to the lingual margin) across the talonid. The protoconid is the highest cusp, directed dorsad and somewhat anterad; it is rounded on the buccal side, flattened on the anterolingual and posterior sides, with a sharp crest passing from the apex linguad to join with a similar crest from the metaconid. The metaconid is somewhat lower than the protoconid but otherwise similar, and together they form the continuous posterior slope of the trigonid, which is slightly concave in the vertical axis. The paraconid is incomplete but evidently was strongly inclined anterad. The talonid is wider than the trigonid and is deeply basin-shaped. The hypoconid was relatively large, but has been mostly broken away. The crista obliqua terminates at the base of the posterior trigonid slope directly posterior to the apex of the protoconid. The entoconid, which has lost its apex, but evidently was somewhat smaller than the hypoconid, is situated at the posterior end of the lingual margin. The hypoconulid is small but distinct, situated close to, but not confluent with, the entoconid; its position and posterad projection give the talonid an asymmetrical outline, as does the deeper sulcus on the buccal margin. A vestigial cingulum occurs on the anterobuccal base of the trigonid, and a more distinct cingulum on the posterior face of the talonid; the latter cingulum passes obliquely from the posterobuccal rim of the crown to the base of the hypoconulid.

\section{REMARKS}

Since this specimen was first described (Russell, 1962), large collections of mammalian teeth have become available from the Lancian of the Lance, Hell Creek, and Edmonton Formations. As Clemens (1966, p. 95 ) pointed out, the Scabby Butte tooth is very similar to lower molars referred to the genus Pediomys. As species of that genus are all based on upper teeth, and as there are no directly associated lower teeth in collections, the assignment of the lower teeth described by Clemens and by Lillegraven $(1969$, p. 47) as Pediomys should be considered as tentative but probably correct. That the Scabby Butte tooth is the $\mathbf{M}_{1}$ of a didelphid similar to, if not conspecific with, the Lancian mandibular ramus referred by Clemens to Pediomys ?krejcii (UCMP 51331) is unquestionable.

\section{Didelphodon? sp.}

REFERRED SPECIMEN

ROM 7848 (Fig. 7A), the badly worn trigonid of a right lower molar, probably $\mathrm{M}_{1}$, from Scabby Butte. 


\section{DESCRIPTION}

This fragment represents a relatively large tooth for the genus. The three cusps formed an asymmetrical triangle, but premortem wear has reduced them to a flat surface without indication of relative cusp size. The anterior cingulum is prominent but becomes rounded and disappears into the anterobuccal side of the trigonid. The lingual wall of the trigonid is distinctly convex, giving it a bulging appearance. The crista obliqua terminates directly posterior to the central core of the protoconid. The narrow remnant of the talonid indicates that it was somewhat wider than the trigonid. The width of trigonid, measured at right angles to the lingual side of tooth as preserved, is $2.9 \mathrm{~mm}$.

\section{REMARKS}

The most distinctive feature of the genus Didelphodon is in the metaconid, which is smaller than the paraconid; this feature cannot be determined in ROM 7848. However, the large size, rather bulbous crown, and position of the crista obliqua support the reference of the specimen to Didelphodon, and the size of the tooth is similar to that of $D$. vorax.

The only other well-known genus of stagodont is Eodelphis, and numerous specimens have been obtained from the upper part of the Oldman Formation. As the Scabby Butte Fauna is stratigraphically between the Oldman Formation and the Scollard Formation, a comparison of ROM 7848 with Eodelphis is warranted. The lower molars in that genus, although comparable in size with that of the Scabby Butte specimen, do not have the lateral bulge. Also, in teeth of Eodelphis a distinct vertical ridge extends from the paraconid down the anterolingual angle of the crown. A comparable ridge, more exaggerated, is present in teeth of Didelphis virginiana, where is serves to brace the lingual side of the hypoconulid (or equivalent) of the preceding tooth. The ridge, present in some but not all lower molars of Didelphodon, is absent in the tooth from Scabby Butte.

\section{Eodelphis? sp.}

\section{REFERRED SPECIMEN}

ROM 7849 (Fig. 7B-D), a worn, broken, right lower molar, probably $\mathbf{M}_{4}$, from Scabby Butte.

\section{DESCRIPTION}

The crown is relatively large for the genus but does not show the lateral bulge. The trigonid is narrow anteroposteriorly. The cusps were evidently well worn in life, and although subsequently remnants were partly broken away, what remains indicates that the paraconid was a large cusp, greatly exceeding the metaconid in size. At the anterolingual side of the trigonid, ventral to the paraconid remnant, there is the lower end of a vertical ridge. The hypoconid, the only cusp remaining of the talonid, is low and bulbous. The crista obliqua appears to terminate at a point more lingual than the apex of the protoconid. The posterior rim of the talonid evidently was large and could have been produced posteriorly, as would be so in $\mathbf{M}_{4}$. The posterior root 
is large and diverges posterad. The length of crown, as preserved, is $3.9 \mathrm{~mm}$; the width of trigonid, measured at right angle to lingual side of crown is $3.15 \mathrm{~mm}$.

\section{REMARKS}

Although imperfectly preserved, this tooth resembles the $\mathbf{M}_{4}$ of Eodelphis cutleri (Woodward) and E. browni Matthew. Resemblances are in the large paraconid, the vertical ridge at the anterolingual angle, the termination of the crista obliqua, and the absence of lateral bulges. A mandibular ramus of $E$. cutleri from the Oldman Formation near Steveville bears an $\mathbf{M}_{4}$ with an accessory cuspule on the lingual margin of the talonid, between the metaconid and the entoconid. There is no trace of this cuspule on ROM 7848, and it is apparently absent in E. browni. The Scabby Butte tooth is identified as $\mathbf{M}_{4}$ mainly by the large, posterad-diverging posterior root.

\section{Order Carnivora? \\ Suborder Fissipeda? \\ Family Miacidae? \\ Genus and species undetermined}

\section{REFERRED SPECIMEN}

NMC 9821 (Fig. 7E-H), trigonid of a left lower molar, from Scabby Butte.

\section{DESCRIPTION}

The trigonid forms a nearly symmetrical triangle, with the subequal paraconid and metaconid as the base and the much higher protoconid as the apex. The three cusps are narrowly conoid, with the centrally-facing slope of each slightly flattened. The ridge extending along the anterior edge of the trigonid, from protoconid to paraconid, is interrupted at its lowest point by a deep cleft, expanded below like a miniature keyhole (carnassial notch of MacIntyre, 1966). A similar cleft between protoconid and metaconid is also suggested. The anterior cingulum is a narrow shelf, sloping buccad, with its terminals below the apices of the protoconid and paraconid respectively. The talonid is missing except for a narrow anterior vestige, which shows the anterior end of the crista obliqua terminating directly ventral to the protoconid-metaconid notch. Width of trigonid, measured at right angles to lingual side, is $2.18 \mathrm{~mm}$.

\section{REMARKS}

The assignment with question of this specimen to the Miacidae (Russell, 1962) met with scepticism by students of Cretaceous mammals, for the oldest accepted member of that family is of Early Paleocene age (Mac Intyre, 1966). Clemens (1966, p. 95) compared it with lower molars of Alphadon ?rhaister and by inference referred it to that taxon. Before restudying NMC 9821 I was prepared to find that it was a didelphid or perhaps an insectivore. But comparison with a large series of lower molars from the Lancian of Bug Creek and with those of miacids from the Paleocene and Lower Eocene confirmed that the specimen is unlike the trigonids of Late Cretaceous 
therians, but resembles a miniature miacid trigonid, i.e., in the subequal paraconid and metaconid, the much higher, symmetrically placed protoconid, and the deep carnassial notch between protoconid and paraconid. In the $\mathbf{M}_{1}$ of Protictis and Didymictis, the best-known Paleocene miacids, the trigonid is higher relative to the talonid, and in addition to the deep anterior carnassial notch, a similar notch occurs between protoconid and metaconid. These features might be expected in the Paleocene descendants of mammals having an $\mathrm{M}_{1}$ similar to NMC 9821. But until the complete tooth is known, the assignment to the Miacidae remains tentative. 


\section{Acknowledgements}

The Pichi Brothers of Nobleford, Alberta, the owners of the property, were most co-operative in permitting access to the mammal site and excavation of the fossil bed. The authorities of the County of Lethbridge granted camping privileges at Keho Lake in 1969. The National Museum of Natural Sciences, through Dr. Dale A. Russell, lent the specimens collected by Langston, and granted permission for their description.

\section{Literature Cited}

BELL, W. A.

1949 Uppermost Cretaceous and Paleocene floras of western Alberta. Bull. Geol. Surv. Can., no. 13, pp. 1-231, 67 pls.

BROWN, B. AND E. M. SCHLAIKJER

1942 The skeleton of Leptoceratops with the description of a new species. Am. Mus. Novit., no. 1169, pp. 1-15, 10 figs.

CLEMENS, W. A.

1963 Fossil mammals of the type Lance Formation Wyoming Part I. Introduction and Multituberculata. Univ. Calif. Publs. Geol. Sci., Vol. 48, pp. 1-105, 51 figs., 1 map.

1966 Fossil mammals of the type Lance Formation Wyoming Part II. Marsupialia. Univ. Calif. Publs. Geol. Sci., vol. 62, pp. 1-122, 77 figs.

1971 [Remarks in litt.] In Fasset, J. E. and Hinds, J. S. Geology and fuel resources of the Fruitland Formation and Kirtland Shale of the San Juan Basin, New Mexico and Colorado. Prof. Pap. U.S. Geol. Surv., no. 676, p. 19.

1973 Fossil mammals of the type Lance Formation Wyoming Part III. Eutheria and Summary. Univ. Calif. Publs. Geol. Sci., vol. 94, pp. 1-102, 32 figs.

FOX, R. C.

1971 Early Campanian multituberculates (Mammalia: Allotheria) from the Upper Milk River Formation, Alberta. Can. J. Earth Sci., vol. 8, no. 8, pp. 916-938, figs. 1-8.

GILL, J. R. AND W. A. COBBAN

1966 The Red Bird section of the Upper Cretaceous Pierre Shale in Wyoming. Prof. Pap. U.S. Geol. Surv., no. 393-A, pp. 1-73, figs. 1-17, pls. 1-12.

IRISH, E. J. W.

1970 The Edmonton Group of south-central Alberta. Bull. Can. Petrol. Geol., vol. 18 , no. 2 , pp. $125-155$, figs. $1-4$.

KIELAN-JAWOROWSKA, Z. AND A. V. SOCHAVA

1969 The first multituberculate from the uppermost Cretaceous of the Gobi Desert (Mongolia). Acta. Palaeont. Pol., vol. 14, no. 3, pp. 355-372.

LANGSTON, W., JR.

1967 The thick-headed ceratopsian dinosaur Pachyrhinosaurus (Reptilia: Ornithischia), from the Edmonton Formation near Drumheller, Canada. Can. J. Earth Sci., vol. 4, pp. 171-186, figs. 1-4, pls. 1-2.

LILLEGRAVEN, J. A.

1969 Latest Cretaceous mammals of upper part of Edmonton Formation of Alberta, Canada, and review of marsupial-placental dichotomy in mammalian evolution. Paleont. Contr. Univ. Kans., art. 50, pp. 1-222, 53 figs. 
MAC INTYRE, G. T.

1966 The Miacidae (Mammalia, Carnivora) Part 1. The systematics of Ictidopappus and Protictis. Bull. Am. Mus. Nat. Hist., vol. 131, art. 2, pp. 115-210, figs. 1-21, pls. 1-20.

RUSSELL, L. S.

1936 New and interesting mammalian fossils from western Canada. Trans. R. Soc. Can., ser. 3 , vol. 30 , sec. 4 , pp. $75-80$, pl. 1.

1962 Mammal teeth from the St. Mary River Formation (Upper Cretaceous) at Scabby Butte, Alberta. Nat. Hist. Pap. Natn. Mus. Can., no. 14, pp. $1-4,6$ figs.

1964 Cretaceous non-marine faunas of northwestern North America. Life Sci. Contr., R. Ont. Mus., no. 61, pp. 1-24.

1970 Correlation of the Upper Cretaceous Montana Group between southern Alberta and Montana. Can. J. Earth Sci., vol. 7, no. 4, pp. 1099-1108, figs. 1-3.

SAHNI, A.

1972 The vertebrate fauna of the Judith River Formation, Montana. Bull. Am. Mus. Nat. Hist., vol. 47 , art. 6 , pp. 323-412, figs. 1-16.

SIMPSON, G. G.

1927 Mammalian fauna of the Hell Creek Formation of Montana. Am. Mus. Novit., no. 267, pp. 1-7, 6 figs.

1929 American Mesozoic Mammalia. Mem. Peabody Mus. Yale, vol. 3, pt. 1, pp. 1-235, 66 figs., 32 pls.

SLOAN, R. E. AND L. VAN VALEN

1965 Cretaceous mammals from Montana. Science, vol. 148, no. 3667, pp. 220 227, figs. $1-6$.

STERNBERG, C. M.

1950 Pachyrhinosaurus canadensis, representing a new family of the Ceratopsia, from southern Alberta. Bull. Natn. Mus. Can., no. 118, pp. 109-120, fig. 5, pls. 17-23.

1951 Complete skeleton of Leptoceratops gracilis Brown from the Upper Edmonton member on Red Deer River, Alberta. Bull. Natn. Mus. Can., no. 123, pp. 225-255, pls. $47-57$.

TOZER, E. T.

1952 The St. Mary River - Willow Creek contact on Oldman River, Alberta. Geol. Surv. Pap. Can., no. 52-3, pp. 1-9.

1956 Uppermost Cretaceous and Paleocene non-marine molluscan faunas of western Alberta. Mem. Geol. Surv. Brch. Can., mem. 280, pp. 1-125, 5 figs., 9 pls.

VAN VALEN, L

1967 The first discovery of a Cretaceous mammal. Am. Mus. Novit., no. 2285, pp. $1-4$.

WILSON, R. W.

1965 Type localities of Cope's Cretaceous mammals. Proc. S. Dak. Acad. Sci., vol. 44, pp. 88-90. 


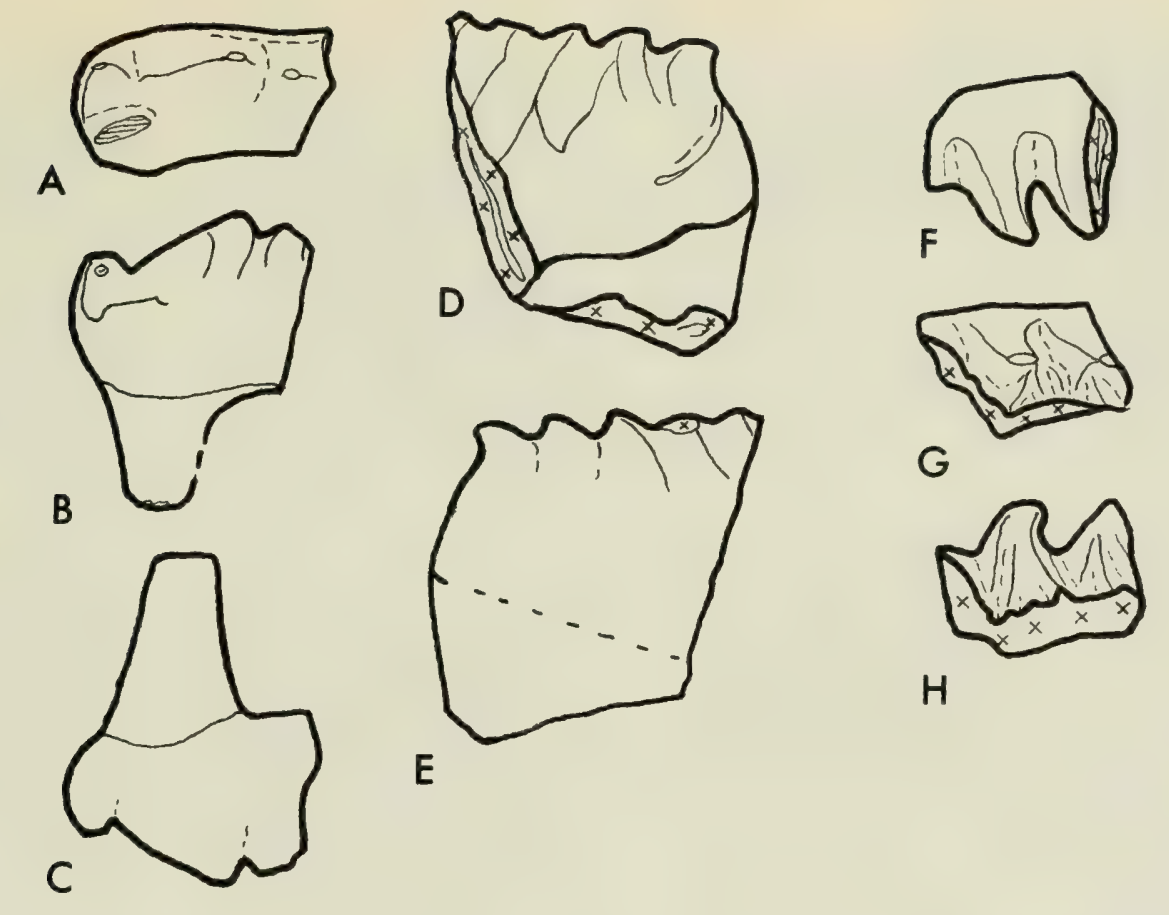

Fig. 1 Conventions are as follows: crosses represent a broken surface; hatching represents a wear facet; where worn to dentine, inner and outer surfaces of enamel shown as a double line; stipple represents pulp cavity; light solid line represents a ridge or crest; dashed line represents a trough, gutter, or valley; circles or ovals represent tips of cusps.
A. Cimolomys gracilis Marsh, NMC 17662, right $\mathrm{P}^{4}$, occlusal view, $\times 10$.
B. Same specimen as A, lingual view, $\times 10$.
C. Same specimen as A, buccal view, $\times 10$.
D. Cimolomys gracilis Marsh, NMC 17663, left $\mathrm{P}_{4}$, buccal view, $\times 10$.
E. Same specimen as $\mathrm{D}$, lingual view, $\times 10$.
F. Cimolomys gracilis Marsh, NMC 17664, fragment of right $\mathbf{M}^{1}$, buccal view, $\times 10$.
G. Same specimen as F, occlusal view, $\times 10$.
H. Same specimen as F, lingual view, $\times 10$.

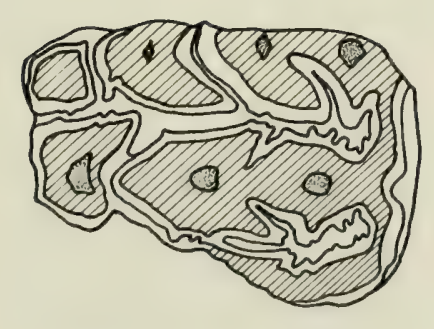

Fig. 2 Meniscoessus conquistus Cope, rom 7847, left $\mathbf{M}^{2}$, occlusal view, $\times 5$. 


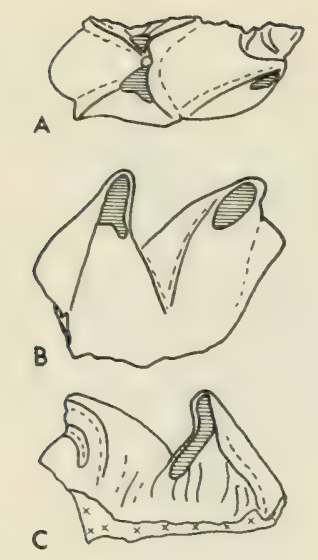

Fig. 3 A. Meniscoessus conquistus Cope, Rom 7850, fragment of right $\mathbf{M}_{2}$, occlusal view, $\times 5$.

B. Same specimen as A, buccal view, $\times 5$.

C. Same specimen as A, lingual view, $\times 5$.

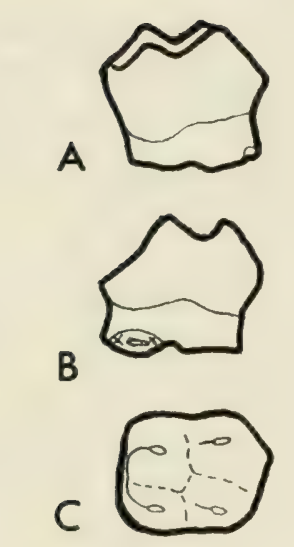

Fig. 4 A. Mesodma cf. thompsoni Clemens, NMC 17665 , left $\mathrm{P}^{3}$, buccal view, $\times 10$.

B. Same specimen as A, lingual view, $\times 10$.

C. Same specimen as A, occlusal view $\times 10$.

Fig. 5 Stereoscopic pairs.

A. Cimolomys gracilis Marsh, NMC 17662, right $\mathbf{P}^{4}$, lingual view, $\times 10$.

B. Same specimen as A, occlusal view, $\times 10$.

C. Same specimen as A, buccal view, $\times 10$.

D. Cimolomys gracilis Marsh, NMC 17663, fragment of left $\mathbf{P}_{4}$, buccal view, $\times 10$.

E. Same specimen as $D$, lingual view, $\times 10$.

F. Cimolomys gracilis Marsh, NMC 17664, fragment of right $\mathbf{M}^{1}$, lingual view, $\times 10$.

G. Same specimen as $F$, occlusal view, $\times 10$.

H. Same specimen as F, buccal view, $\times 10$.

I. Meniscoessus conquistus Cope, $\operatorname{ROM} 7846, \mathrm{P}^{2}$ ?, buccal view, $\times 10$.

J. Same specimen as I, occlusal view, $\times 10$.

K. Meniscoessus conquistus Cope, ROM 7847 , left $\mathbf{M}^{2}$, occlusal view, $\times 5$. 

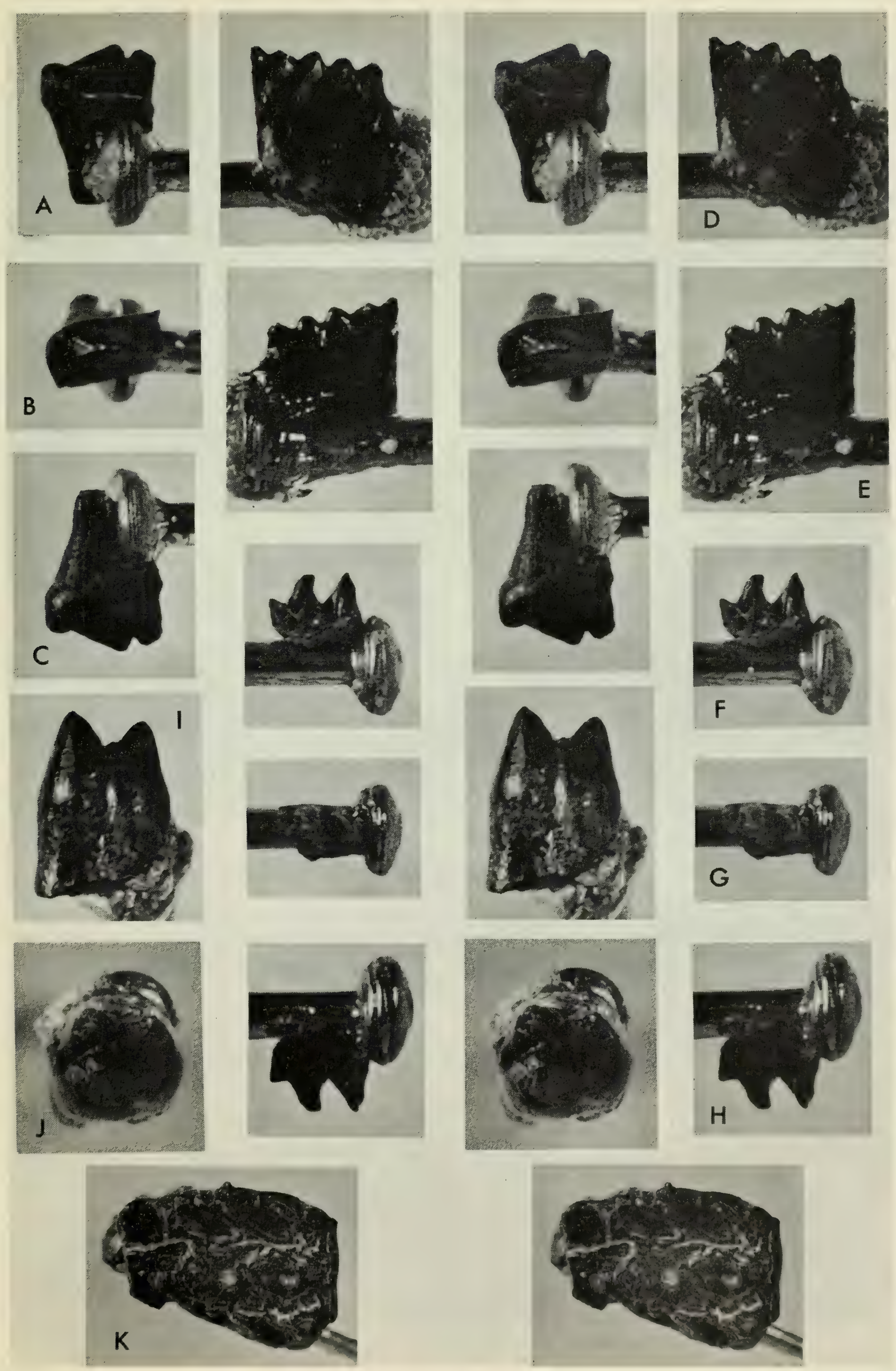
Fig. 6 Stereoscopic pairs.

A. Meniscoessus conquistus Cope, ROM 7850 , fragment of right $\mathbf{M}_{2}$, occlusal view, $\times 5$.

B. Same specimen as A, buccal view, $\times 5$.

C. Same specimen as A, lingual view, $\times 5$.

D. Mesodma cf. thompsoni Clemens, NMC 17665 , left $\mathrm{P}^{3}$, lingual view, $\times 10$.

E. Same specimen as 4 , buccal view, $\times 10$.

F. Same specimen as 4 , occlusal view, $\times 10$.

G. Cimolodon nitidus Marsh, NMC 17667, right $\mathbf{M}_{2}$, occlusal view, $\times 20$.

H. Pediomys cf. cooki Clemens, NMC 21307, buccal portion of right $\mathbf{M}^{2}$ ?, occlusal view, $\times 10$.

I. Pediomys cf. krejcii Clemens, NMC 9820 , right $\mathbf{M}_{1}$, occlusal view, $\times 10$.

J. Same specimen as I, buccal view, $\times 10$.

$\mathrm{K}$. Same specimen as I, lingual view, $\times 10$. 

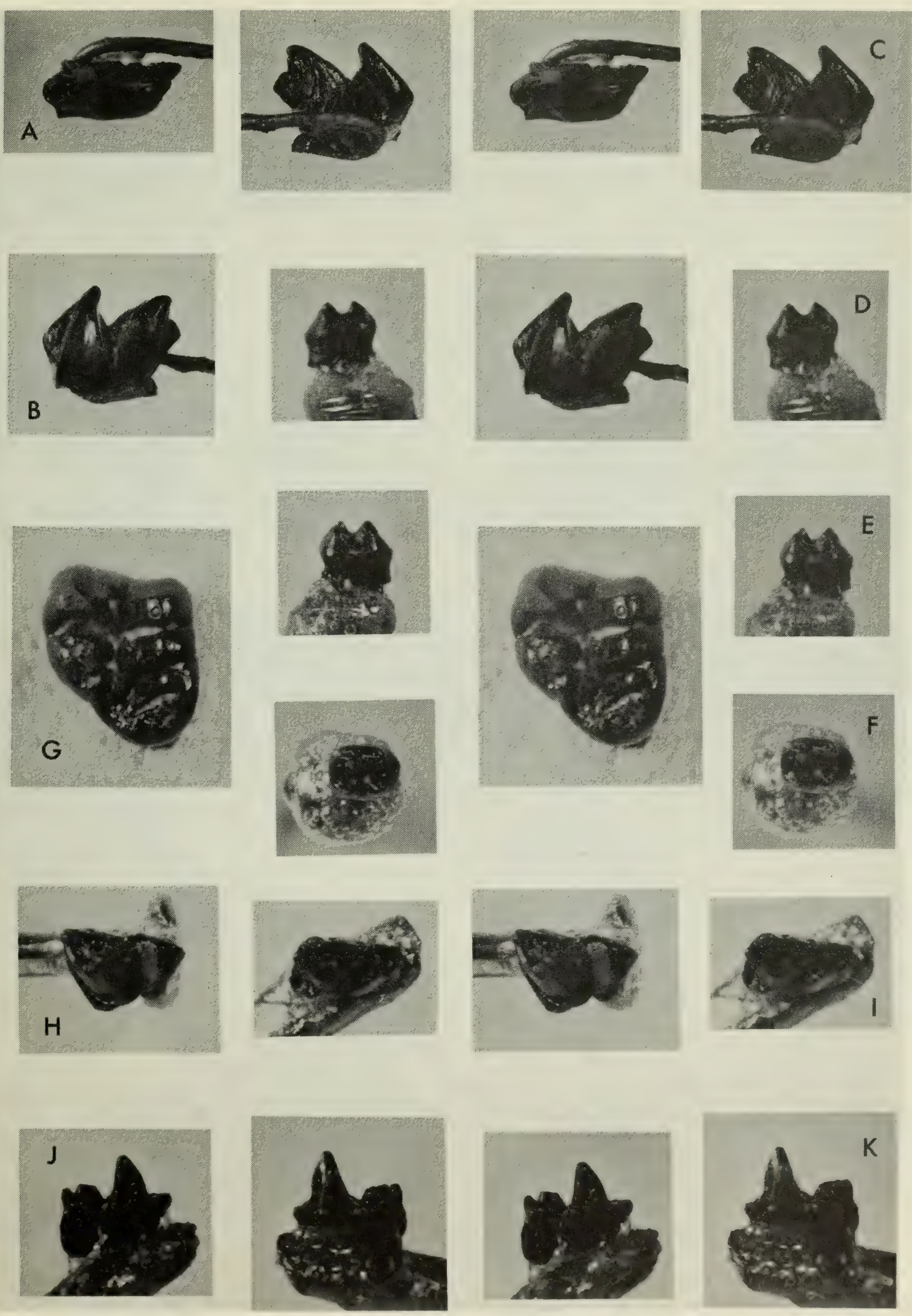
Fig. 7 Stereoscopic pairs.
A. Didelphodon? sp., ROM 7848, worn trigonid of right lower molar, occlusal view, $\times 10$.
B. Eodelphis? sp., Rom 7849, worn and broken right lower molar, occlusal view, $\times 5$.
C. Same specimen as $B$, buccal view.
D. Same specimen as B, lingual view.
E. Miacid?, NMC 9821, trigonid of left lower molar, occlusal view, $\times 10$.
F. Same specimen as $E$, buccal view, $\times 10$.
G. Same specimen as $E$, lingual view, $\times 10$.
H. Same specimen as E, anterior view, $\times 10$. 

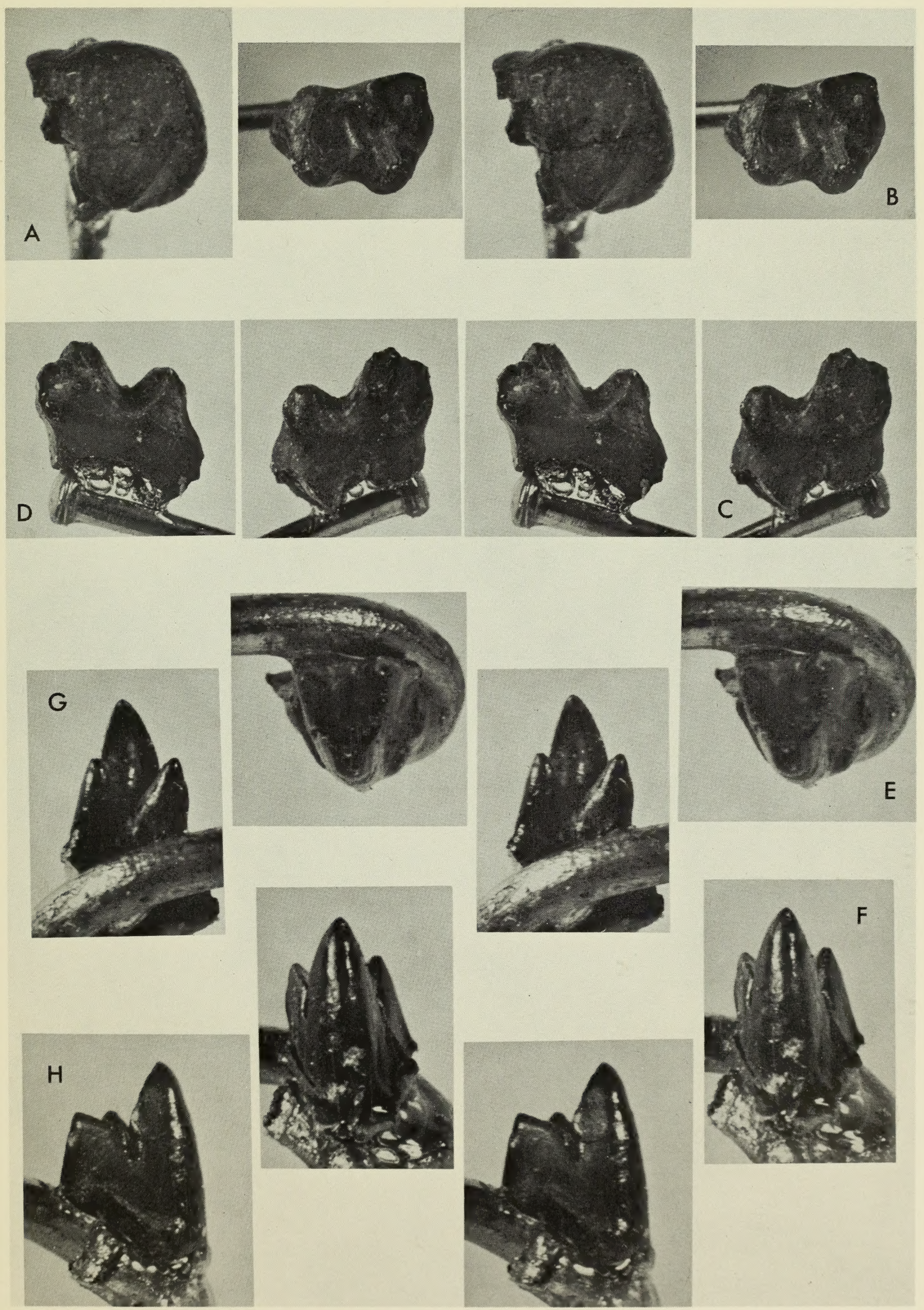

